北海道木古内町に飛来したソデグロッ゙ルについて

森口和明

北海道函館市新川町 6-1，广040

\title{
A RECORD OF THE SIBERIAN WHITE CRANE Grus leucogeranns FOUND IN HOKKAIDO, JAPAN
}

\author{
Kazuaki MORIGUCHI
}

6-1 Shinkawacho, Hakodate, Hokkaido 040

Summary An individual of the Siberian White Crane was observed at Kikonaicho of Hokkaido from 14 Oct. to 5 Dec. 1977. External characters and adaptive features associated with the feeding habits were mentioned.

日本では数回の記録しかないソデグロヅル Grus leucogeranus が 1 羽、1977年 10 月 14 日から 12 月 5

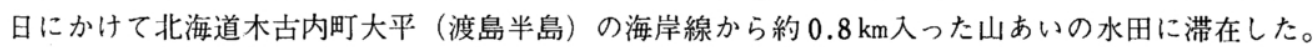
筆者は10月14日13時、渡島支庁から依頼を受けて現地で種の確認を行ない、以降延21回にわたって現 地で観察をしたので、その結果を報告する。

形態および大きさ：趾跡測定と写真による判定から、翼長約 600 、嘴峰長約 190 、跗蹠約 240 、内 趾約 80 、中趾 106 、外趾約 $80 \mathrm{~mm}$ 。翼を下げ、あるいは開いた時のみ、翼角、初列風切羽、雨覆の黒色 部が現れる。初列風切羽は11枚（清悽、1952）であるが、小斑ながら黒色部は次列風切数枚にも及ぶ。 嘴は褐色で部分的に濃淡がある。顔頭部の裸出部は赤色で、黄褐色の剛毛を生ずる。脚は赤色だが、 跱蹠の前縁に暗緑色部がある。

顔頭部の赤色は、赤褐色、淡赤色、さらには赤味がなくなる等、様々に変化する。脚の赤色も多少 変化するが、頭部程激しくなく、頭部の変化と必ずしも対応しない。

食 性：次のものを採食しているところを観察した。そのうち、オモダカ属の越冬芽・ドジョウ・ ミミズを主に食べた。いずれも土中の生物である。

ドジョウ Misgurnus anguicaudatus. C

ミミズ Lumbricidae sp.

アキアカネ Sympetrum frequens

マルタニシ Ciangopaludina chinensismalleata

ケラ Gryllotalpa africana

オモダカ属 Sagittaria sp.

スギナ属 Equisetum sp.

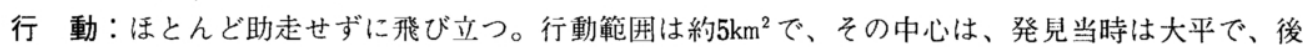
にその南々西約 $4.7 \mathrm{~km}$ の建川に移った。降り立って採食のために歩く範囲は $100 \mathrm{~m}^{2}$ 以内であり、土中 生物を採食するときは、さらに狭い。水田などの泥湿地で採食するときは、瞬膜を閉じ、嘴から頭部 裸出部全部まで土中に突っ込む。や、硬い水田刈跡地では、嘴を半開きにして土を掘る。時に土塊を はさんで取り除いて深さ15 $19 \mathrm{~cm}$ の穴を掘り、オモダカ属、ミミズ等を採り、そばに水があれば洗つ て食べる。トンボは嘴を突き出して捕える。踭に水を含んで上に向けて水を飲む。羽づくろいを行な う時は、とくに頭部の污れをていねいに落す。羽づくろいが終ると、羽ばたきや、翼や脚を伸ばす動 作をし、あくびを何回もして仮眠に入ることが多い。水浴は、水溜りに座って行ない, 一浴び毎に羽 
づくろいをする。水浴後、羽ばたきをして最後に翼を開いたま、、一瞬停止する行動を繰り返す。

ねぐらと採食場との間の移動の様子は次のとおり。日没前後、採食しながら鳴き始め、さらに 2 3 分後、採食を全くやめて首を伸し、鳴きながら落ち着きなく歩き回る。次第に声の間隔が短くなり、 急に体を低くして助走せずに飛び上り、旋回しながら上昇して、ねぐらへ向かう。最初に声を出した ときから飛び立つまでの時間は、6 分間。採食をやめるのは、暗くなって食物を探しにくくなるから と思われる。採食場への飛来は、日の出後である。

渡去した 12 月 5 日頃までには、 4 回の積雪があり、表土および水面が凍結を始めたので、採食困難 となり渡去したと思われる。12月 4 日は、気温上昇により、前夜の降雪の雪解水で水浴し、また採食 していたが、渡去推定の 5 日朝は凍結していた。以後、枚ぐらであった水田地带、河川等を調べたが、 発見できなかった。

考 察：飛来地の採食場所は泥湿地のある水田であった。前述のとおり、眼の瞬膜をおろして頭部 裸出部まで土中に突込む採食行動、頭部の污れを落す行動は、他の種のツル類には見られないもので、 頭部裸出部と関連した適応的な進化を示していると思われる。

\section{引用文 献}

清棲幸保。1952，日本鳥類大罒鑑：225。講談社, 東京.

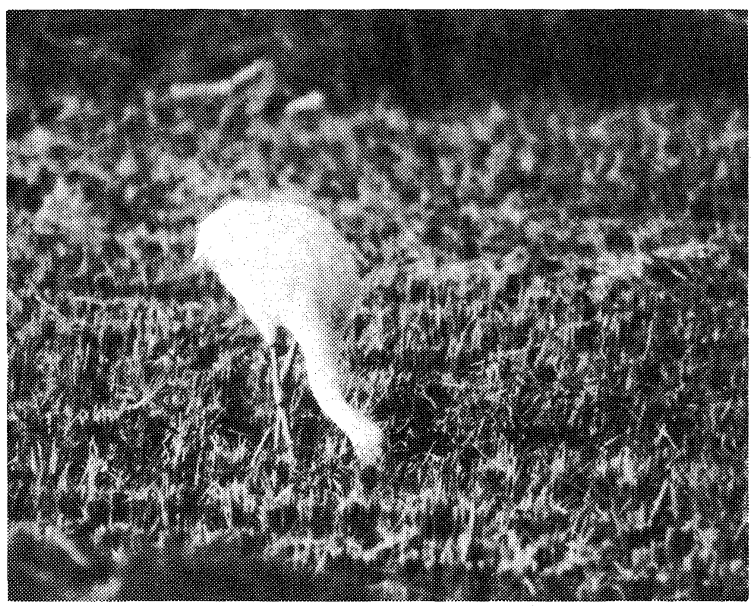

Fig. 1. A Siberian White Crane feeding in rice field. Note the beak inserted deeply into mud.

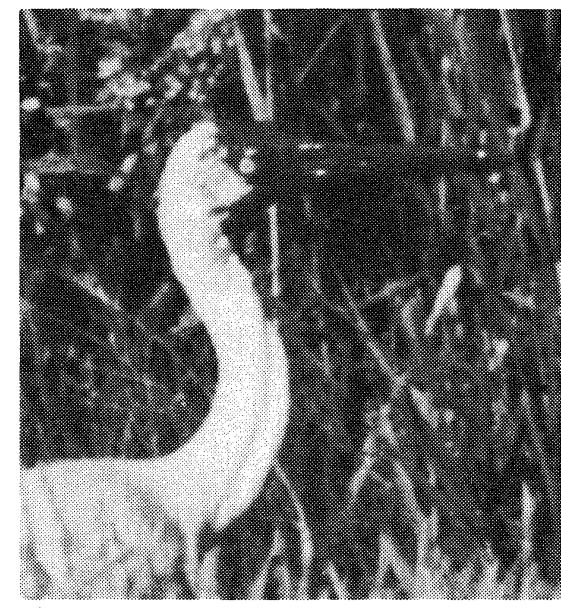

Fig. 2. The same Siberian White Crane as in Fig. 1. Note the face which became black through the feeding. 